\author{
DAWID MARIA OSIŃSKI \\ Instytut Literatury Polskiej \\ Uniwersytet Warszawski
}

\title{
BIBLIOTEKA JAKO PRZESTRZEŃ POZNANIA
}

\author{
Słowa kluczowe: biblioteka, poznanie, Józef Kallenbach, Carl Spitzweg, mól książkowy
}

Keywords: library, cognition, Józef Kallenbach, Carl Spitzweg, bookworm

\section{Wejście do biblioteki}

Literackie obrazy bibliotek pełnią różne funkcje. Są one uzależnione od tego, jakie miejsce zostaje wyznaczone bibliotece w strukturze tekstu literackiego oraz jakie sensy nadają jej bohaterowie. Ważne jest także to, dlaczego protagoniści wybierają bibliotekę jako przestrzeń doświadczenia związaną z procesem dojrzewania, odkrywania tajemnicy świata i siebie, a także natury rzeczywistości. Obrazy bibliotek w literaturze pokazują również przestrzeń szczególną, ponieważ najczęściej związaną z inicjacją rozumianą jako poznawanie skomplikowanej relacji znaczeń określających miejsce poznającego podmiotu w świecie zdarzeń. Określają figury intelektualistów (ludzi czytających i rozumiejących) i w związku z tym dotyczą problemów inteligencji, skoro mówią o jej podstawowej dyspozycji wiążącej się z rozumieniem i nazywaniem świata.

Przykładem tekstu pokazującego ciekawe oblicze biblioteki jest nowela Józefa Kallenbacha Przygoda bibliotekarza (1888), nieznana w zasadzie do 2014 roku $^{1}$, wydobyta i przypomniana przez Józefa Malinowskiego i Marka Wedemanna $^{2}$. Kallenbach wykorzystuje konwencję noweli z motywem snu, bliską skądinąd i parabolom pozytywistów ${ }^{3}$, i różnorodnym nowelistycznym tekstom

${ }^{1}$ Autograf noweli znajduje się z zbiorach Polskiej Akademii Nauk Archiwum w Warszawie (materiały Józefa Kallenbacha, sygn. III-43, j. 3). Przewodnik po zasobie Archiwum PAN, ed. Hanna Krajewska et Alicja Kulecka, et al. (Warszawa: Wyd. PAN, 1999), 148.

${ }^{2}$ Józef Kallenbach, „Przygoda bibliotekarza”, ed. Józef Malinowski, Marek Wedemann, Wiek XIX. Rocznik Towarzystwa Literackiego im. Adama Mickiewicza, vol. VII(XLIX) (2014): 437-444. Dalej jako PB i numer strony cytowanej.

${ }^{3}$ Anna Martuszewska, Pozytywistyczne parabole (Gdańsk: Wyd. Uniwersytetu Gdańskiego, 1997), 96-105. 
modernistów ${ }^{4}$. Zastosowanie specyficznej poetyki onirycznej, „snu we śnie”, służy postawieniu pytań o charakter i źródła poznania.

W artykule przywołuję również szereg innych utworów, aby wprowadzić tło kontekstowe. Dzieła te nie tworzą sieci jednoznacznych intertekstualnych powiązań z nowelą Kallenbacha. Przywołania pozwalają jednak na przypuszczenia interpretacyjne bądź hipotezy badawcze sygnalizujące możliwe (bo wynikające z podobieństw tematycznych) pola problemowe wspólne dla tych utworów i Przygody bibliotekarza.

\section{Pragnienie bibliofila. Kontekst Waltera Scotta i Aleksandra Michaux}

Tematem miniatury Kallenbacha jest przygoda tytułowego bibliotekarza, który pewnego zimowego dnia przeszukiwał biblioteczne półki w celu znalezienia konkretnej „zazieleniałej książeczki” (PB, 440). Po odkryciu pożądanego woluminu zatopił się w lekturze i odciął się od rzeczywistości. Unieważnił tym samym reguły czasu, co w warstwie fabularnej znalazło odzwierciedlenie w zamknięciu biblioteki.

Poszukiwanie za wszelką cenę upragnionej książki i czytanie jej niczym „książki zbójeckiej” to schemat fabularny wielu tekstów literatury pierwszej połowy XIX wieku i przedstyczniowej. Ale inaczej niż ukazywani tam młodzieńcy zaczytani w „szalonych” i niebezpiecznych książkach - nasz bohater jest nie młodzieńcem, lecz starcem.

Jako jeden z pierwszych na gruncie polskim literacki obraz starca w typie faustowskim (przedstawionego jako człowiek o wątłym zdrowiu, ale ogromnej potencji umysłowej i mądrości), poszukującego upragnionej książki, proponuje Aleksander Michaux w króciutkim szkicu Antykwariusz. Szkic do powieści (1866). Bohater Mirona to sześćdziesięciopięcioletni Sylwester, nazywany przez niektórych „szpargałem”, kolekcjoner i zbieracz osobliwości (manuskryptów, urn, zbroi, obrazów, książek i szkiców, kałamarza Bacciarellego, sztyletu Borgii, biurka Staszica, Kronik Kromera), z których intensywnie korzysta podczas codziennej pracy ${ }^{5}$. Od trzydziestu lat poszukuje starodruku Petrarki. Jak wynika $z$ apostrofy skierowanej do diabła, jest gotów zaprzedać mu duszę. Miron wykorzystuje tu zarówno topos faustycznego paktu, jak i motyw lucyferyczny, wzięty zapewne z ballady Pani Twardowska bądź Tukaj Mickiewicza. Jakkolwiek potrzeba posiadania upragnionego inkunabułu renesansowego poety nie ma w sobie nic z chęci posiadania księgi zbójeckiej, gubiącej tych, którzy przedrą się

${ }^{4} \mathrm{O}$ specyfice polskiej nowelistyki modernistycznej vide Hanna Ratuszna, „Błysk obrazu” $-z z a$ gadnień krótkich form narracyjnych w literaturze Młodej Polski (Toruń: Wyd. Naukowe UMK, 2009).

${ }^{5}$ Miron [Aleksander Michaux], „Antykwariusz. Szkic do powieści”, Kłosy, no. 33 (1866): 385-386. 
przez jej karty, to samo wprowadzenie snu, w którym bohater widzi pędzącego na czarnym koniu szatana w żelaznej koronie, trzymającego „Rime di Petrarca”, wydaje się istotne. Dokonuje się tu (podobnie jak w Mickiewiczowskiej balladzie, choć temat czego innego dotyczy) podpisanie cyrografu, którego treść jest prosta: skarb w postaci poezji Petrarki w zamian za duszę antykwariusza. Wprowadzenie konwencji snu i dwukrotne powtórzenie formuły „dziwny sen” na początku akapitów potwierdza, że bohater ma do czynienia z dziwnością istnienia. Schorowany starzec, przez dwadzieścia pięć lat pracujący nad tłumaczeniami Dantego, nieoczekiwanie umiera. Szkic kończy odnarratorski komentarz opowiadający historię kolekcji antykwariusza w ciągu dwóch tygodni po jego śmierci.

Nowela Kallenbacha może więc mieć umocowanie w lekturze miniatury Mirona, którego skądinąd autor Przygody bibliotekarza cenił. Nie można również wykluczyć, że pomysł podobnego widzenia Kallenbach mógł zaczerpnąć z powieści Waltera Scotta Antykwariusz (1816), przetłumaczonej w 1828 roku na język polski przez Henryka Emanuela Glücksberga. Pojawia się tu postać Jonatana Oldenbuka - niedoszłego prawnika, który decyduje się zostać kolekcjonerem ksiąg, map, militariów, precjozów, a za zdobycie pierwodruku Rime Petrarki jest w stanie oddać duszę diabłu ${ }^{7}$. W powieści Scotta lucyferyczny pierwiastek umożliwia pokazanie zgubnych skutków fiksacji polegającej na skupieniu całego życia wokół pragnienia posiadania wymarzonego tomu sonetów.

\section{Biblioman. Kontekst Konstantego Marii Górskiego}

Przygodę bibliotekarza warto byłoby również zestawić z późniejszą o osiem lat nowelą Konstantego Marii Górskiego Biblioman (1896) ${ }^{8}$. Krakowski intelektualista, badacz, edytor i literat również wykorzystuje motyw poszukiwania książki i konwencję oniryczną, a choć czyni to inaczej niż Kallenbach, podobnie jak on potwierdza niepewność sytuacji poznawczej i znaczenie zatarcia granicy między jawą a snem. Nowela dotyczy losów bibliomana Sztremera. Jeździ on po kraju w celu odnalezienia tomiku poetyckiego z czasów insurekcji kościuszkowskiej, bo istnienie tomiku potwierdziłoby istnienie tyrtejskiej poezji zaangażowanej czasów późnego Oświecenia. Nie jest wykluczone, że Górski znał miniaturę Kallenbacha z autografu. Wiele ich łączyło. Górski urodził się

${ }^{6}$ Ibidem, 386.

${ }^{7}$ Walter Scott, Antykwariusz, trans. E...G... [Henryk Emanuel Glücksberg] (Warszawa: Wyd. Franciszek Salezy Dmochowski, Wyd. „Gazety Korespondenta”, 1828).

${ }^{8}$ Konstanty M. Górski, Biblioman. Nowela. Z konkursu literackiego „Czasu”, Kraków 1896. Nowelę tę interpretowałem w studium „Konstantego Marii Górskiego lektura Oświecenia”, Prace Filologiczne. Literaturoznawstwo, no. 7(10) (2017): 115-130. 
w 1862 roku, a Kallenbach w $1861^{9}$, w tym samym środowisku pobierali nauki. Bliskie były ich filologiczne upodobania naukowe oraz zainteresowania i wybory zawodowe, współtworzyli galicyjskie środowisko intelektualne.

\section{Cmentarz. Kontekst Józefa Ignacego Kraszewskiego i Antoniego Krumana}

W noweli Kallenbacha przestrzeń biblioteki przypomina zziębniętemu i głodnemu molowi książkowemu „cmentarz pracy kilkowiekowej” (PB, 441). Taki obraz biblioteki wydaje się ważny w literaturze polskiej ${ }^{10}$. Ostrzega bowiem przed możliwą śmiercią kultury i dziedzictwa, bo przecież biblioteka jako miejsce gromadzące wytwory myśli i pracy pokoleń jest skarbnicą pamięci dziejowej. Przykład takiego widzenia biblioteki daje Józef Ignacy Kraszewski - autorytet podkreślający znaczenie pamięci i utrwalania śladów minionego. Mam tu na myśli jego wiersz o incipicie Książka? Śliczna! świeci złotem!..., datowany na 1877 rok $^{11}$. Oczywiście nie jest to jedyny tekst w dorobku autora Dziadunia, który mówiłby o znaczeniu biblioteki i sposobie jej funkcjonowania, ale wydaje się znamienny jako kontekst omawianej przeze mnie noweli. Kraszewski wskazuje na skutki nie tyle nieczytania, ile cenzusu wydawniczego książek, które nie znajdują nabywców z powodu ceny, a więc w konsekwencji projektuje literacki obraz śmierci kultury:

Książka? Śliczna! świeci złotem!

Przepych? Ale co mi potem?

Co po trupie w złotej trumnie?

Na półkach dmącym się dumnie,

$\mathrm{Z}$ grzbietem strojnym, z szatą świetną,

Gdy mu i kart nie rozetną!

Kiedy czasem przez pół wieka

Nie przemówi do człowieka!

Książka niechaj idzie w świat,

$\mathrm{Z}$ dworu na folwark, do chat.

A gdy na szmaty podarta

Zostanie ostatnia karta,

I w błoto brudne wciśniona

${ }^{9}$ Vide Irena Maciejewska, „Konstanty M. Górski”, in Obraz literatury polskiej XIX i XX wieku. Literatura okresu Młodej Polski, ed. Kazimierz Wyka, Artur Hutnikiewicz, Mirosława Puchalska (Kraków: PWN, 1973), vol. III, 439.

${ }^{10} \mathrm{~W}$ literaturze światowej taki typ widzenia chyba najciekawiej został zrealizowany w zasadzie dopiero pod piórem Carlosa Ruiza Zafóna w sensacyjnej topice powieści Cień wiatru (La Sombra del Viento, 2001) z magicznym miejscem w Barcelonie, wtajemniczonym znanym jako Cmentarz Zapomnianych Książek, do którego prowadzi bohatera powieści, dziesięcioletniego Daniela Sempere'a, jego ojciec (księgarz i antykwariusz mieszkający z chłopcem nad antykwariatem).

${ }^{11}$ Zapis w gazecie brzmi: „Drezno, z 17 na 18 grudnia (1877 r.) w noc bezsenną”. Józef Ignacy Kraszewski, [„Książka? Śliczna! świeci złotem!...”], Zorza, no. 1 (1878): 1-2; Tydzień, no. 9 (1878): 3. 
Na śmiecisku kędyś skona,

Oddaj jej pokłon głęboki:

Tu leżą Rycerza zwłoki!! [w. 1-16] ${ }^{12}$.

Obraz biblioteki jako cmentarza, podobny jak w noweli Kallenbacha, pojawia się również w wierszu zapoznanego poety Antoniego Krumana. A mówię o tym dlatego, że wiersz oznaczony w wydaniu prasowym jako *** o incipicie Cmentarze i biblioteka został opublikowany na łamach „Tygodnika Mód i Powieści” w numerze 32 (więc w drugim półroczu) w tym samym roku 1888, w którym powstał autograf noweli Kallenbacha. Zbieżność ta wydaje się zastanawiająca. Edytorzy Przygody bibliotekarza wskazują, że sam autor w rękopisie zapisuje datę „12.[0]1.[18]88”13. Można więc przypuszczać, że nowelista pierwszy posłużył się formułą biblioteki podobnej do cmentarza. Trudno orzec, czy Kruman (publikujący w „Tygodniku Mód i Powieści” liczne wiersze) mógł mieć w ręku rękopis tekstu Kallenbacha i nie można jednoznacznie uzasadnić domniemania zależności.

Wiersz Krumana mówi o znaczeniu ludzkiej pamięci i konsekwencjach niepamiętania o tych, którzy przyczynili się do budowania trwałych relacji międzyludzkich:

Cmentarze i biblioteka

Jednakie mają znaczenie:

Tam giną kości człowieka,

Tu myślom grozi zniszczenie.

I tu, i w grobów popiele,

$\mathrm{Z}$ tych, których imię zostało,

Wezwanych bardzo jest wiele,

Ale wybranych zbyt mało.

A z czasem, zwykłą koleją,

Gdy pamięć odmówi straży,

Wszystkie te księgi zbutwieją,

Znikną pamiątki z cmentarzy.

Bo tylko w ludzkiej pamięci,

Ten idzie z rodu do rodu,

Kto życie ludziom poświęci,

I przejdzie w życie narodu [w. 1-16] ${ }^{14}$.

W noweli Kallenbacha przestrzeń biblioteki - ów „cmentarz pracy kilkowiekowej” - pełna jest biustów i posągów stojących między regałami książek. Wśród tak umeblowanej przestrzeni bohater wybrawszy najdłuższy stół na miejsce

${ }^{12}$ Józef Ignacy Kraszewski, [„Książka? Śliczna! świeci złotem!...”], Zorza, no. 1 (1878): 1-2.

${ }^{13}$ Józef Kallenbach, Przygoda bibliotekarza, ed. Józef Malinowski, Marek Wedemann, 439.

${ }^{14}$ Antoni Kruman, „***”, Tygodnik Mód i Powieści, no. 32 (1888): 250. 
do snu, a kilka egzemplarzy książek na wezgłowie, na granicy półsnu i jawy doświadcza przedziwnego wrażenia: atakują go książki wylatujące z bibliotecznych szaf i regałów ${ }^{15}$. Krzyczące książki czekały na taki moment setki lat, rzucone w „zimną otchłań” (PB, 442) i nieczytane. Dlatego kiedy teraz zdarza się okazja odwetu za lata ich nieczytania, tom starego Seneki „syczy”, starodruki i inkunabuły spragnione są uścisku, a osiemnastowieczne encyklopedie piszczą: „Nie do niego [Seneki], do nas, do nas zajrzyj!” (PB, 443) i tłoczą się „długim rzędem po ciele" (PB, 443) bohatera:

Ze wszystkich ścian, od dołu aż pod sklepienia, leciało coś na mnie rojem skrzydlatym. Zanim mogłem ruch jakiś uczynić, już byłem niewolnikiem... Mrowie ksiąg i broszur ożyło: grube folianty z dolnych półek z szatańskim śmiechem opadły mi [na] nogi i ręce, w powietrzu fruwały seciny grubszych i drobniejszych książek [PB, 442].

Biblioteka z jej woluminami ożywającymi w obecności bohatera staje się opresywna, skoro bunt książek ma na celu zmianę myślenia bibliotekarza. To uświadamia, że materia, którą ten się na co dzień zajmuje, jest materią żywą. Materia się buntuje, ponieważ domaga się głosu i życia. Kallenbach pokazuje tu bunt tradycji, wobec której zastosowano regułę zamknięcia w przestrzeni bibliotecznych półek, więc nie może ona pełnić swojej funkcji korektorki codzienności. Można by powiedzieć, że Kallenbach próbuje pokazać, iż dziedzictwo wielowiekowej kultury zgromadzone na półkach bibliotecznych istnieje jako duchowy wytwór pracy intelektualnej pokoleń. Ale trwa wówczas, kiedy jest czytane i poddawane refleksji, odżywa każdorazowo dzięki kolejnym lekturom. Zmurszała i nieodkurzana biblioteka jest dla Kallenbacha ważnym komponentem myślenia o problemach tożsamościowych i narodowych polskiej kultury, a więc o znaczeniu wspólnego dziedzictwa i wspólnego kodu kulturowego ludzi korzystających z jej zasobów.

\section{Biblioteka jako tekst kultury. Kontekst Wacława Berenta}

Jeden z najciekawszych przykładów literackich, pokazujących, co się dzieje, kiedy przedkłada się bios życia nad logos tradycji, daje Wacław Berent w Oziminie (1911). Jednym z ważnych mitów konstytuujących doświadczenie intelektualisty i inteligenta staje się tu mit lamp Lukrecjusza i biblioteki jako przestrzeni nieczytelnej, jako miejsca nieodwiedzanego. To miejsce, które podczas długiej nocnej rozmowy rodaków w salonie baronostwa Niemannów okazuje się martwe. Staje się ono przestrzenią ważną, lecz labiryntową dla Wandy, która tu opowiada Ninie swoją historię i rozgląda się z zaciekawieniem „po tych półkach,

${ }^{15}$ Niewykluczone, że tekstem-prototypem dla noweli Kallenbacha był obraz „gadających książek" zawarty w Pieśni IV z Monachomachii Ignacego Krasickiego. 
czyniących z wielkiego pokoju labirynt stosów książek sięgających aż po sufit"16. Jest również znaczące dla profesora z Krakowa. Próbuje on egzegezy księgozbioru, wybierając umiejętnie tytuły dzieł z jego zawartości, jednak biblioteka traci wyrazistość i staje się przestrzenią zagubienia:

\begin{abstract}
Wyrywając książki z półek na traf, zabłąkał się profesor niebawem w tym lesie. Oto minął rychło pisarzy Wieku Złotego, w tak zwanym Baroku natknął się na pyszne wydawnictwa oliwskie, za czym, pociągnięty zewnętrznym luksusem wydawnictw Groelowskich i puławskich, wstąpił myślą w senatorskie koło postaci o posągowym geście i jasnym spojrzeniu wieku Oświecenia - na tę nową falę światowego przypływu, która szczytu swego nie sięgnąwszy runęła w dziejów odmęty, by odwieczną współpracę ducha u warsztatu ludzkości i tradycyjny kontakt z jego po świecie mistrzami przekazać oręża współdziałaniu po Europie ${ }^{17}$.
\end{abstract}

Celowo przywołuję w tym miejscu późniejszą chronologicznie powieść z diagnozą funkcji biblioteki. W jednej z najważniejszych powieści pokolenia polskich modernistów wydobyte jest bowiem to, o czym mówi nowela Kallenbacha - co się dzieje, kiedy zanikowi ulega podstawowa rola, jaką spełnia biblioteka. Podobnie jak cmentarz, biblioteka jest ważnym tekstem kultury ${ }^{18}$. Skoro jest podobna do nieotwieranego latami grobowca dziejów, to można przypuszczać, że książki są odpowiednikiem spoczywających w nim ciał, choć nie porównuje się tu wprost książek do ciał zmarłych. Taka antropomorfizacja ma jeszcze jedną cechę: wskazuje na możliwość odradzania się, ponownego „ożycia” po uśpieniu książek. Potwierdza to wykorzystanie przez Kallenbacha mitu eleuzyńskiego i mitu rezurekcyjnego.

\title{
6. Przygoda. Sytuacje graniczne
}

Wejście do biblioteki na początku jest dla bohatera Przygody bibliotekarza wkroczeniem do świata znanego, pewnego i dającego poczucie stabilności, oferującego możliwość znalezienia tego, czego się szuka. Bibliotekarz jest u siebie $\mathrm{z}$ racji fachu, jednak tytułowa formuła przygody zwraca uwagę na nowy typ przeżywania świata. Przygoda zawsze wiąże się z ryzykiem i zawieszeniem ustalonego porządku. Ważny okazuje się w obrazie Kallenbacha inicjacyjny charakter tego doświadczenia. Nie jest ono racjonalnie i z góry zaplanowane, ale właśnie „przygodne”, wiążące się z przypadkowością i zaskoczeniem, z wpisanym weń ryzykiem niepewności i nieznanego.

${ }^{16}$ Wacław Berent, Ozimina (Warszawa: PIW, 1995), 61.

${ }^{17}$ Ibidem, 135.

${ }^{18}$ Warto przywołać niektóre z nowszych publikacji na temat cmentarza jako tekstu kultury. Sławomir Sikora, „Cmentarz. Antropologia pamięci”, Konteksty, no. 1 (1987): 57-62; Jacek Kolbuszewski, Cmentarze (Wrocław: Wydawnictwo Dolnośląskie, 1996); Anna Długozima, Cmentarze jako ogrody żywych i umarlych (Warszawa: Wydawnictwo Sztuka ogrodu Sztuka krajobrazu, 2011); Prace Filologiczne. Literaturoznawstwo, no. 2(5) (2012) Nekropolie. 
Oczywiście ważna jest również specyfika poruszania się w przestrzeni biblioteki wykonawcy zawodu, do którego dyspozycji i kompetencji należą katalogowanie, kolekcjonowanie, porządkowanie - jednym słowem opieka na co dzień nad książkami jako podopiecznymi. Bibliotekarz zdradza również cechy człowieka wykształconego humanistycznie, a więc potencjalnie kogoś, kto uważnie przygląda się natrafionym przypadkiem znaleziskom, konfiguracjom skatalogowanych tak, a nie inaczej książek. Katalogując i porządkując, nadaje swoiste sensy strukturze zbioru książek w bibliotece, układa bowiem taksonomię zbioru, która poprzez skodyfikowaną strukturę umożliwia stworzenie taksonomii poznania. Szukając poszczególnych woluminów w celu scalenia księgozbioru, znajduje często przygodnie i przypadkiem nieoczekiwane elementy kolekcji bibliotecznej. Dokonuje wówczas rozpoznania bibliotecznego świata. Co prawda irytuje go sytuacja szukania i niemożności znalezienia owej „zazielenionej książeczki”, ale w końcu jego zmagania kończą się powodzeniem.

Po czasie okazuje się jednak, że wejście do biblioteki, a w konsekwencji uwięzienie w niej (bohater został w niej zamknięty od zewnątrz), staje się doświadczeniem traumatycznym. Przypomina sytuację graniczną, skazującą na podległość czy niemożliwość, lecz także na znalezienie się w przestrzeni śmierci:

Czułem, jak uchodzi ze mnie życie. Żal ścisnął mi serce, żal za niespełnionymi planami, za szczytnym urojeniem, które mnie gnało do pracy, a które ludzie sławą nazywają. Nigdy nie oceniłem lepiej wartości życia - toteż z głębi duszy wydarł mi się okrzyk: „Ratunku!” [PB, 443].

Martwa, ciemna i głucha przestrzeń biblioteki przypomina mityczny Hades. Przepływa się tu od okna do okna i nie można znaleźć wyjścia, a klucznik (współczesny Charon?) nie okazuje się tu przewodnikiem ani kimś, kto mógłby uwolnić bohatera. Groteskowa sytuacja ataku tysięcy woluminów, utrzymana w gotyckiej wręcz konwencji grozy (zima, pustka, ciemność, puste i wysokie okna), ujawnia, że biblioteka może stać się przestrzenią groźną, nieprzyjazną, co więcej - przestrzenią uwięzienia.

Chciałbym przywołać raz jeszcze Kraszewskiego. Sądzę, że jego wczesny obrazek Bedlam. Rzecz lekarsko-filozoficzna (1833, data wyd. 1838) stanowi ważne tło tematyczne dla Przygody bibliotekarza. Postać Tymoteusa Olausa Godmana, niespełna trzydziestoletniego byłego profesora uniwersytetu w Oxfordzie, pacjenta londyńskiego szpitala psychiatrycznego, bibliografa próbującego za wszelką cenę poznać naturę świata ${ }^{19}$, przeraża niewyobrażalnym reżimem codziennych

${ }^{19}$ Józef Ignacy Kraszewski, „Bedlam. Rzecz lekarsko-filozoficzna”, in idem, Wędrówki literackie, fantastyczne i historyczne (Wilno: Drukarnia S. Blumowicza, 1838), vol. I, 173-211. Warto dodać, że Kraszewski był również autorem szkicu Przechadzka po bibliotece zawartego w II tomie Wędrówek literackich, fantastycznych i historycznych (Wilno: Drukarnia S. Blumowicza w Domu JO. Xięcia Ogińskiego, 1839), p. II, 48-96, będącego literackim katalogiem różnego rodzaju białych kruków literatury polskiej i obcej (zwłaszcza Szekspira) z krótkimi notami, wypisami i komentarzami. 
lektur, przy niemożliwości zapanowania nad nieskończonością procesu lektury. Zaspokojeniem dawnych pragnień bohatera okazują się sny, w których widzi kobiety siedzące na stosach książek i pergaminów.

Późniejszy bohater noweli Kallenbacha co prawda nie przypomina bibliografa zatopionego w katalogu biblioteki. Nie jest też szaleńcem, choć przeraża go absurdalna sytuacja, w której się znalazł, powodująca zwątpienie w rozum. Ale dziwny sen, specyfika poznawania biblioteki i zachłanność w poszukiwaniach lekturowych są mu właściwe, tak jak bohaterowi Kraszewskiego.

\section{Prawda i poznanie}

Przerażony i bezradny bibliotekarz atakowany przez książki woła o pomoc, a na ratunek przybywa nadzwyczajny blask. Człowiek doznaje iluminacji, ponieważ jawi się przed nim figura Niewiasty (alegoria prawdy i poznania), przypominająca anioła. Przemawia do bohatera, ujawniając paradoks poznania - Prawda jest zawsze nieuchwytna dla człowieka, ale upragniona i potrzebna do życia:

„Nie ważysz się patrzeć na mnie, a szukasz mnie wszędzie. Lękasz się blasku mych oczu, a za jeden ich promyk życie byś rad oddał. Dziecię słabe! Nabierz otuchy...”. „Kto jesteś, Pani Potężna? Jakim Cię uczcić mianem?”. „Odkąd ród człowieczy na ziemi, odtąd się biedzi nad moim mianem...” [...] „Prawda! Prawda! Prawda!” [PB, 443-444].

Alegoryczna figura Prawdy, objawiająca się bohaterowi, przedstawiona jest na wzór Madonny z renesansowych obrazów, ponieważ w przekonaniu bohatera jest obdarzona mocą zbawczą i ma przynieść wyzwolenie:

Tu blask nadzwyczajny uderzył me oczy i z wzruszeniem nie dającym się opisać uczułem, że ciężar gniotący mnie opada. Spojrzałem: z tysiąca ksiąg ani śladu - tumany pyłu duszącego mnie przed chwilą zmieniły się w blasku promiennym w obłok złocisty, na którym nieziemskiej piękności Niewiasta się unosiła. Porwałem się i padłem na kolana przed tą oswobodzicielką... Boski uśmiech zdobił twarz cudowną, której rafaeliczny wdzięk z silną prostotą Michała Anioła szedł o lepsze [PB, 443].

Tekst jest wart odnotowania nie tylko dlatego, że otwiera go anonimowe motto: „Na półkach leżą książki, a w nich zabalsamowane dusze pisarzy" (ibidem, 48), określające specyfikę myślenia Kraszewskiego o bibliotece jako przestrzeni umarłej, lecz także ze względu na wstępne rozpoznania pisarza zbieżne z tym, o czym będzie po latach jako starzec pisał w przywoływanym przeze mnie wierszu. Kraszewski nazywa bibliotekę „sublimatem przeszłości” (ibidem, 48), do której - jak do zacisznej enklawy - zaprasza, zwracając się bezpośrednio do swego potencjalnego odbiorcy: „Chodźcie za mną, chodźcie i drzwi zamkniemy za sobą; niech się teraz świat kłóci, śmieje, płacze, nas tu nie dojdą swary, szyderstwa i łzy, utoniem w przeszłości - oto macie krzesła wygodne, stół do pisania, mapy, dla starych dzieci obrazki, dla ludzi książki, rękopisma, pamiątki wszystkich wieków i krajów, prawie wszystko to, co się zostaje z wielkiego szumu wieków. - Sublimat przeszłości - treść życia milionów ludzi”. Ibidem, 48. 
Pytania o status prawdy i charakter jej poznania to pytania odwieczne. Dotyczą umiejętności rozumienia i nazywania świata, a także wiążą się z istotą metafizyki, estetyki, etyki, moralności, jak i doświadczenia. Zadając je, Kallenbach próbuje uporać się z problemem, czy prawda w ogóle możliwa jest do pomyślenia i jak się do niej dochodzi, jak się ją bada i studiuje, co komunikuje ona człowiekowi. Pisarz sugeruje swą miniaturą, że prawdę zdobywa się w mozolnym doświadczeniu, w niekończącej się, bardziej intuicyjnej niż intelektualnej, lekturze świata i znaków, jakimi mówi do człowieka.

\section{Jak poznać bibliotekę: sen}

Konwencja pierwszoosobowej narracji oraz wprowadzenie sytuacji onirycznej (ze snu budzi narratora-bohatera Matka, odkrywając czytelnikowi tym samym, że przywołana historia była jedynie snem) pokazuje również, że prawda jest subiektywna, jest dana w indywidualnym doświadczeniu, stąd podkreślenie potencjalności jej jednostkowego poznania przez każdego człowieka. Sytuacja snu daje literackie alibi realistycznej noweli Kallenbacha ${ }^{20}$. Autor Przygody bibliotekarza musi wprowadzić konwencję oniryczną dającą potwierdzenie, że przywołana historia jest potencjalnie możliwa jedynie we śnie. Ale jeśli we śnie, to nowela skłania do myślenia, jaki status i charakter ma sen w życiu człowieka ${ }^{21}$. Fabuła tej miniatury ujawnia groteskowość sytuacji, w jakiej znalazł się tytułowy bibliotekarz. Gdyby nie konwencja snu, nowela mogłaby dawać zupełnie inne pola odczytań i lokowałaby tekst Kallenbacha zupełnie inaczej. Oniryzm i konwencja prozy spowiedniczej uświadamiają, że przychodząca do bohatera we śnie Prawda jest czymś tylko domniemanym. Ostatnie zdanie noweli brzmi: „Bo mówcie sobie, co chcecie: widziałem Prawdę - choć we śnie" (PB, 444).

To potwierdza, jak ważne staje się przekonanie o widzeniu prawdy. Paronomazyjna zależność: „widzieć - wiedzieć” wskazuje tu na odwołania do Platońskiego Fajdrosa i Timajosa, ujawniające znaczenie idealistycznej teorii poznania i wartość iluzji poznawczej, która kształtuje odbiór rzeczywistości. Ale iluzja ta ma jeszcze jedno znaczenie dla bohatera. W chwilach zwątpienia i rezygnacji (o czym odbiorca tekstu dowiaduje się z ostatnich zdań noweli, pokazujących retrospektywnie mola książkowego w przestrzeni bibliotecznego pyłu) daje

${ }^{20}$ Literacka propozycja Kallenbacha podobna jest do pomysłu fabularnego Prusa ze Snu (1890): wprowadzenie snu biednego studenta medycyny, majaczącego w gorączce, umożliwia pisarzowi-realiście pytanie o granice i możliwość zbadania posągu Rzeczywistości, a więc o specyfikę poznania prawdy o świecie, o znaczenie cierpienia jako miernika ludzkiej egzystencji, o zależność choroby i zdrowia, a przede wszystkim o doświadczenie pamięci rejestrowane w ciągu snu i choroby.

${ }^{21} \mathrm{Na}$ ten temat vide Jan Tomkowski, Mój pozytywizm (Warszawa: Wydawnictwo IBL, 1993), 99-173; Aneta Mazur, Transcendencja realistów. Motywy metafizyczne w polskiej i niemieckiej prozie II połowy XIX wieku (Opole: Wyd. Uniwersytet Opolski, 2001), 355-389. 
poczucie pewności, nawet jeśli ta pewność okupiona jest przeczuciem o niestałości prawdy. Może Kallenbach wyraża tu przekonanie, że sen jest pełnoprawnym (bo osobniczym, dostępnym każdej istocie myślącej na swój własny sposób) elementem ludzkiego doświadczenia, skoro wpisuje się w ludzką pamięć.

\section{Mól książkowy. Kontekst Carla Spitzwega}

Biorąc pod uwagę dotychczasowe rozpoznania związane z Przygoda bibliotekarza Kallenbacha, zamiast zamknięcia przywołam kontekstowo dzieło ikonograficzne, związane z podobnym typem wrażliwości artystycznej na bibliofilskie doświadczenie penetrowania biblioteki w celu poszukiwania książek, a zatem poznania i prawdy. Jest to, jak sądzę, ważne malarskie przedstawienie samej idei poszukiwania, obecnej w noweli Kallenbacha (a także w Bibliomanie Górskiego). Myślę tu o jednym z „wariantów” obrazu malarza i poety epoki niemieckiego biedermeieru - Carla Spitzwega (1808-1885) pt. Der Bücherwurm (w dosłownym tłumaczeniu Mól ksiażkowy, publikowany i znany również pod tytułem Der Bibliotekar; Bibliotekarz), namalowanym w okolicy $1850 \mathrm{roku}^{22}$. Obecnie obraz ten znajduje się w Muzeum Georga Schäfera w Schweinfurcie w Niemczech ${ }^{23}$. Co prawda nacisk kładzie się tu na szukanie nie tekstu patriotycznego (jak w przypadku noweli Górskiego) ani niesprecyzowanej „zazielenionej książeczki” (jak w przypadku Kallenbacha), lecz tekstu z dziedziny metafizyki. Jednak Przygoda bibliotekarza sprawia wrażenie, jakby była prozatorską ekfrazą obrazu Spitzwega. $\mathrm{Na}$ obrazie tym starszy człowiek pokazany jest, gdy stoi na drabince w bibliotece przed regałem z książkami oznaczonym podpisem „Metaphysik”. Mól książkowy, zaczytany $\mathrm{w}$ jednym $\mathrm{z}$ woluminów, $\mathrm{z}$ nosem $\mathrm{w}$ książce, stoi na podeście $\mathrm{i}$ trzyma w ręku, pod pachą i między kolanami inne książki, wyszukane z przepastnej toni bibliotecznej i zapewne zabrane do dalszej lektury. Przestrzeń biblioteki wyznaczają również dwa ważne elementy. Są to: stojący w lewym rogu na podłodze globus, stanowiący podstawowy dziewiętnastowieczny artefakt biblioteczny, oraz namalowane na suficie w konwencji pałacowo-dworskiej freski stalowo-niebieskiego nieba, z kłębiącymi się chmurami, zasłaniającymi firmament. Obraz zasłoniętej przestrzeni nieba na suficie koresponduje z poszukiwaniem wśród mnóstwa różnych woluminów na regale z podpisem „Metafizyka” dzieła, którego się pożąda. Wydaje się, że Kallenbach musiał znać ten obraz, który miał możliwość zobaczyć w Niemczech choćby podczas odbywanych tam studiów. Mógł więc napisać Przygodę bibliotekarza jako literacki komentarz do obejrzanego obrazu Spitzwega.

${ }^{22}$ Fritz Novotny, Painting and Sculpture in Europe 1780-1880 (Yale: Yale University Press, 1992), 227. Vide https://pl.wikipedia.org/wiki/Carl_Spitzweg\#/media/File:Carl_Spitzweg_021.jpg (acc. 16.06.2017).

${ }^{23}$ Eckhard Bernstein, Culture and Customs of Germany (Westport: Greenwood Press, 2004), 163. 
10. $* * *$

Przywołanie dzieł stanowiących tło kontekstowe Przygody bibliotekarza pozwoliło uwypuklić filozoficzne sensy noweli. Biblioteka jako przestrzeń poznania prawdy, a więc rozpoznania możliwości postrzegania świata i ludzkiej tożsamości, staje się przestrzenią trudnego poznawania natury rzeczywistości. Tę czytać należy z pokorą wobec różnych jej znaków, które cały czas mówią, czasami poprzez pamiątki cmentarzy, czasami dzięki snowi, a czasami dzięki pułapkom, w które wrzuca człowieka sam proces poznania.

\section{LIBRARY AS THE SPACE OF COGNITION}

\section{Su m m a ry}

The article is a study of the ways of interpreting the image of the library in Józef Kallenbach's short story Przygoda bibliotekarza (The Adventure of the Librarian, 1888). The presented examples demonstrate the multi-dimensional meaning of library as an intellectual problem and cognition space. The author shows Kallenbach's points of view concerning library as a motif which helps to pose questions about convention and conception of realism and, as a consequence, about Kallenbach's view on culture. The present discussion also sheds light on a few important texts which create a context to analyse the short story by Kallenbach. Intertextual allusions can be helpful in understanding the main problem presented in The Adventure of the Librarian. The paper focuses on the meaning of the library as a graveyard as well as on dream and onirism as a literary convention which expresses the possibilities of cognition and asks what realism in Polish literature of the end the $19^{\text {th }}$ century in Kallenbach's case actually is. The article discusses the aesthetic differentiation of the library in the short story The Adventure of the Librarian by Józef Kallenbach and the painting Der Bücherwurm (Bookworm) by Carl Spitzweg. The author tries to prove that The Adventure of the Librarian could be an epic ekphrasis to Spitzweg's painting. 